\title{
Glycerol Teichoic Acid as a Common Antigenic Factor in Lactobacilli and Some Other Gram-positive Organisms
}

\author{
By M. ELISABETH SHARPE AND J. H. BROCK \\ National Institute for Research in Dairying, University of Reading, Berkshire \\ K. W. KNOX \\ Institute of Dental Research, United Dental Hospital, Surrey Hills, \\ N.S.W. 2010, Australia \\ A. J. WICKEN \\ School of Microbiology, University of New South Wales, P.O. Box I, \\ Kensington, N.S.W. 2033, Australia
}

(Received 22 February 1972; revised 23 August 1972)

\section{SUMMAR Y}

An antiserum prepared against a strain of Lactobacillus acidophilus gave a reaction of identity with $\mathrm{HCl}$ extracts of strains of lactobacilli, some pediococci and leuconostocs and Staphylococcus aureus. The antigenic determinant, isolated from a strain of $L$. case $i$ Ro-94 was identified as a membrane glycerol teichoic acid. Purified membrane lipoteichoic acids from Lactobacillus serological groups A, B, C, D and F and streptococcal polyglycerophosphate also reacted with the antiserum. The antigen-antibody reaction was partially inhibited by $\alpha$-glycerophosphate and strongly inhibited by glycerol-phosphoryl-glycerol-phosphorylglycerol, but was not inhibited by glucose. It was concluded that the antiserum was reacting with the common polyglycerophosphate backbone of the membrane teichoic acids in the reacting strains.

\section{INTRODUCTION}

An antiserum against one strain of Lactobacillus acidophilus gave very strong reactions against acid extracts of many lactobacilli. Preliminary observations (Sharpe, 1970) suggested the presence of a common membrane-located antigenic factor in all lactobacilli, distinct from the group specific factors which are either teichoic acids (Sharpe, Davison \& Baddiley, I964; Mills, I969; Knox, Hewett \& Wicken, I970; Wicken \& Knox, I970; Knox \& Wicken, I97I) or polysaccharides (Knox, I963). The occurrence of this common reaction with different groups of bacteria has been examined by the qualitative precipitin method, and with different preparations of membrane teichoic acid and lipoteichoic acid by the quantitative precipitin method.

\section{METHODS}

Reacting antiserum. The original antiserum to Lactobacillus acidophilus A22 or further antisera from the same rabbit were used, designated as antiserum A22/300.

Strains of bacteria examined. All were laboratory strains from the National Collection of Dairy Organisms, the National Collection of Type Cultures, the American Type Culture Collection or from the National Institute for Research in Dairying collection.

Culturing of organisms. All strains were incubated for $18 \mathrm{~h}$ at the appropriate temperature 
of $30^{\circ} \mathrm{C}$ or $37^{\circ} \mathrm{C}$. For preparation of antisera, bacteria were grown in $100 \mathrm{ml}$ MRS broth (de Man, Rogosa \& Sharpe, I960), with meat extract omitted. Most bacteria for acid extraction were grown in $100 \mathrm{ml}$ modified MRS broth, with I \% (w/v) Trypticase (BBL) replacing Oxoid peptone, yeast extract reduced to $0.2 \%(\mathrm{w} / \mathrm{v})$, meat extract omitted, the concentration of phosphate increased to $0.5 \%$ (w/v) $\mathrm{K}_{2} \mathrm{HPO}_{4}+0.5 \%$ (w/v) $\mathrm{KH}_{2} \mathrm{PO}_{4}$ and $0.02 \%(\mathrm{w} / \mathrm{v})$ cysteine added. Streptococci of Lancefield serological groups A-C, E-M and $\mathrm{O}$ were grown in $100 \mathrm{ml}$ yeast glucose broth (Naylor \& Sharpe, 1958). Bifidobacteria and clostridia were cultured anaerobically in a McIntosh and Fildes jar under $90 \% \mathrm{H}_{2}+10 \%$ $\mathrm{CO}_{2}$, and all other organisms aerobically. For preparation of membrane teichoic acid I6 1 modified MRS broth was used; filtered glucose final concentration $2 \%(\mathrm{w} / \mathrm{v})$ was added afterwards.

Preparation of acid extracts. Organisms were harvested by centrifugation and $0.4 \mathrm{~g}$ wet wt of bacteria extracted at $100{ }^{\circ} \mathrm{C}$ for 10 min with $2 \mathrm{ml}$ of $0.05 \mathrm{~N}-\mathrm{HCl}$ in $0.15 \mathrm{M}-\mathrm{NaCl}$ and neutralized with I $\mathrm{N}-\mathrm{NaOH}$ (Lancefield, I933).

Preparation of membrane teichoic acid from Lactobacillus casei. A component reacting serologically with antiserum A22/300 was present in TCA extracts of lactobacilli and in the soluble fraction from disintegrated organisms. To determine whether a membrane teichoic acid might be responsible for the reaction, membrane teichoic acid from Lactobacillus casei RO-94 (NCDO I 5I) was isolated, since wall teichoic acid is absent (Baddiley \& Davison, 196I). During preparation of the membrane teichoic acid, samples were monitored serologically by ring precipitin test with antiserum A22/300, to check that antigenic activity was present. Bacteria were harvested by centrifugation (yield $90 \mathrm{~g}$ wet wt), washed in $0.02 \mathrm{M}$-phosphate/ $0.15 \mathrm{M}$-saline ( $\left.\mathrm{pH}_{7} \cdot 2\right)$ and broken on the Braun homogenizer (Shandon) for $4 \mathrm{~min}$. Whole bacteria were separated by centrifugation at $2000 \mathrm{~g}$ for $4 \mathrm{~min}$ and the soluble fraction was separated from the walls by centrifugation at $17000 \mathrm{~g}$ for $30 \mathrm{~min}$. To remove most of the nucleic acids, the soluble fraction was acidified with $5 \mathrm{~N}-\mathrm{HCl}$ to $\mathrm{pH} 3.5$, left overnight at $4{ }^{\circ} \mathrm{C}$, centrifuged at $2000 \mathrm{~g}$ for $\mathrm{I} 5 \mathrm{~min}$ and the precipitate discarded. The resultant supernatant was added to the walls, the $\mathrm{pH}$ adjusted to $7 \cdot 6$, and treated with trypsin (Sigma Chemical Co., London), $0.5 \mathrm{mg} / \mathrm{ml}$; ribonuclease (Koch-Light Laboratories Ltd., Colnbrook, Buckinghamshire), $0.05 \mathrm{mg} / \mathrm{ml}$; and deoxyribonuclease (Koch-Light Laboratories), I $\mu \mathrm{g} / \mathrm{ml}$ overnight at $37^{\circ} \mathrm{C}$. After heating to $100{ }^{\circ} \mathrm{C}$ for $\mathrm{I} 5 \mathrm{~min}$, debris was removed by centrifugation at $38000 \mathrm{~g}$ for $\mathrm{I} \mathrm{h}$, the supernatant dialysed against distilled water and concentrated to about $\mathrm{I} 5 \mathrm{ml}$.

This preparation was dialysed against $0.02 \mathrm{M}$-potassium phosphate buffer, $\mathrm{pH} 6.85$, and passed through a column $(0.9 \times 20 \mathrm{~cm})$ of DEAE cellulose (Whatman DE 52) equilibrated with the same buffer. The column was first eluted with $100 \mathrm{ml}$ of the phosphate buffer, and then with $200 \mathrm{ml}$ of a sodium chloride gradient in the same buffer. The gradient was prepared using a constant volume mixing chamber and arranged so that the concentration of sodium chloride in the buffer entering the column was initially zero and $0.5 \mathrm{M}$ at the end of the run. Fractions were tested for absorbance at $260 \mathrm{~nm}$ and for serological activity.

Fractions showing serological activity were pooled, dialysed and lyophilized. Nucleic acids still present were separated from antigenic material by chromatography on a Sepharose $4 \mathrm{~B}$ column $(40 \times 2.5 \mathrm{~cm})$ (Pharmacia Ltd, London, W.5.), using $0.0 \mathrm{I}$ M-tris $+0.05 \mathrm{M}$-sodium chloride ( $\mathrm{pH} 7 \cdot \mathrm{I})$ as eluant (Young \& Jackson, 1966). Fractions which were serologically active and had an absorbance of less than 0.2 at $260 \mathrm{~nm}$ were dialysed and freeze-dried. The lyophilized material was dissolved in $10 \mathrm{ml}$ of $10 \%(\mathrm{w} / \mathrm{v})$ trichloracetic acid at $4{ }^{\circ} \mathrm{C}$ and precipitated with $50 \mathrm{ml}$ of ethanol. The product was reprecipitated and washed successively in acetone, ethanol and ether. The final yield of purified material was $12 \mathrm{mg}$. 
Other preparations of teichoic acids. Membrane lipoteichoic acids were obtained by phenol extraction followed by column chromatography (Wicken \& Knox, 1970) from strains representing serological groups A (Lactobacillus helveticus $\mathrm{NCIB} 8025$ ); B (L. casei NIRD H83I); C (L. casei RO-94); D (L. plantarum NCIB 7220); and F (L. fermenti NCTC699I). The lipoteichoic acids differ in the nature and extent of their glycosidic substitution (Wicken \& Knox, I97I).

An atypical glycerol teichoic acid was isolated from walls of Bacillus stearothermophilus B65 (Wicken, 1966). Wall glycerol teichoic acids from Lactobacillus plantarum AB4I and cro6 in which glucose is linked to glycerol in the backbone of the polymer (Adams, Archibald, Baddiley, Coapes \& Davidson 1969) were kindly supplied by Dr A. L. Davison, University of Newcastle-upon-Tyne. A preparation of polyglycerophosphate (unsubstituted glycerol teichoic acid) from a group A streptococcus, type 3, (McCarty, 1959) was kindly provided by Dr M. McCarty, Rockefeller Institute, New York.

\section{Serological tests}

Preparation of antisera. Organisms were washed once and resuspended in $0.15 \mathrm{M}$-saline and heated to $60^{\circ} \mathrm{C}$ for $\mathrm{I} h$. Rabbits were inoculated intravenously at intervals of 3 to 4 days with $\mathrm{I} \mathrm{ml}$ of a suspension of organisms adjusted to an extinction value of 0.55 (Hilger Biochem absorptiometer at $580 \mathrm{~nm}$ ).

Ring precipitin test. The technique of Jones \& Shattock (1960) was used.

Immunodiffusion. The slide test as described by Mansi (I957) was used.

Precipitin titre. Potencies of some antigen preparations were determined by making doubling dilutions of antigen in $0.15 \mathrm{M}-\mathrm{NaCl}$ and testing against antiserum A22/300 by the ring precipitin test. The titre was the highest dilution of antigen to give a clear precipitin ring after $5 \mathrm{~min}$.

Quantitative precipitin test. The method described by McCarty \& Lancefield (1955) was used. The maximum amount of antibody precipitated by the lipoteichoic acid preparations and polyglycerophosphate was determined by mixing antiserum (I $5 \mu \mathrm{l}$ ) with varying amounts $(5$ to $20 \mu \mathrm{g}$ ) of each teichoic acid. Protein was estimated by the method of Lowry, Rosebrough, Farr \& Randall (I95I) or of Heidelberger \& MacPherson (I943), using bovine serum albumin as a standard.

Inhibitors of precipitin test. Glucose, $\alpha$-glycerophosphate and glycerol-phosphorylglycerol-phosphoryl-glycerol $\left(\mathrm{G}_{3} \mathrm{P}_{2}\right)$ were used. $\mathrm{G}_{3} \mathrm{P}_{2}$ was prepared from cardiolipin (General Biochemicals, Chagrin Falls, Ohio, U.S.A.) by mild deacylation (Wilkinson, I968).

For the quantitative precipitin inhibition test appropriate dilutions of these inhibitors in $0.15 \mathrm{M}-\mathrm{NaCl}$ were mixed with antiserum, incubated for $30 \mathrm{~min}$ at $37^{\circ} \mathrm{C}$, and the antigen then added as for the quantitative precipitin test.

\section{Chemical analysis}

Total phosphorus was estimated by the method of Chen, Toribara \& Warner (1956). Hexose was estimated by the phenol sulphuric acid method of Dubois, Gilles, Hamilton, Rebers \& Smith (1956).

Glucose was estimated by the glucose oxidase method (Bergmeyer \& Bernt, I965) after hydrolysis of the antigen in a sealed tube for $2 \mathrm{~h}$ at $100{ }^{\circ} \mathrm{C}$ in $2 \mathrm{~N}-\mathrm{HCl}$ and neutralization with $4 \mathrm{~N}-\mathrm{NaOH}$.

Ester-linked alanine. Samples were incubated with $0.2 \mathrm{~N}-\mathrm{NaOH}$ at $37^{\circ} \mathrm{C}$ for $2 \mathrm{~h}$ (Chatterjee, 1969) and after neutralization free amino acid was estimated by the method of Rosen (1957). 
Table 1. Serological ring precipitin reactions of antiserum to Lactobacillus acidophilus A22 tested against $\mathrm{HCl}$ extracts of different micro-organisms

\begin{tabular}{lccc}
\multicolumn{1}{c}{ Genus or species } & $\begin{array}{c}\text { No. of } \\
\text { species } \\
\text { examined }\end{array}$ & $\begin{array}{c}\text { No. of } \\
\text { strains } \\
\text { tested }\end{array}$ & $\begin{array}{c}\text { Serological } \\
\text { reaction } \\
\text { (No. } \\
\text { positive) }\end{array}$ \\
Lactobacillus & I2 & I02 & 97 \\
Pediococcus & 5 & 6 & 3 \\
Leuconostoc & 3 & 6 & 3 \\
Staphylococcus aureus & I & 3 & 3 \\
Sporolactobacillus & I & I & I \\
Bifidobacterium & 5 & 1 & 0 \\
Clostridium & 4 & 6 & 0 \\
Bacillus (B. coagulans and B. stearothermophilus) & 2 & 3 & 0 \\
Group D streptococci & 3 & 8 & 0 \\
Group N streptococci & 2 & 4 & I weak \\
Groups A, B, C, E-M, O streptococci & - & 32 & 0
\end{tabular}

Chromatography. Samples (about $2 \mathrm{mg}$ ) were hydrolysed in $2 \mathrm{~N}-\mathrm{HCl}(0 \cdot 2 \mathrm{ml})$ at $100{ }^{\circ} \mathrm{C}$ for $2 \mathrm{~h}$; evaporated to dryness over potassium hydroxide and phosphorus pentoxide, and examined by paper chromatography using solvents and reagents described by Baddiley, Buchanan, Rajbhandary \& Sanderson (1962).

\section{RESULTS}

Precipitin reactions of acid extracts of different micro-organisms against $A 22 / 300$ antiserum

Antigen preparations giving a negative ring precipitin reaction were also negative with the immunodiffusion test. All extracts were therefore tested by ring precipitin test and positive reactions were confirmed by immunodiffusion test. Acid extracts of bacteria ( 187 strains) belonging to a number of different genera were tested against antiserum to Lactobacillus acidophilus A22/300 (Table I). In all extracts positive by ring precipitin test the immunodiffusion test showed a reaction of identity, indicating that the same antigenic determinant was present in each organism.

Location of teichoic acid from Lactobacillus casei RO-94. When L. casei RO-94 was disrupted on the Braun homogenizer and the walls separated by centrifugation, the soluble fraction had a precipitin titre of 64 against antiserum A22/300. Precipitin titres of successive saline washings of the wall fraction indicated that the antigenic factor was readily removed from the wall. Heating of walls suspended in $0.02 \mathrm{M}$-phosphate buffer at $70{ }^{\circ} \mathrm{C}$ for $30 \mathrm{~min}$ or treatment with trypsin also removed the antigenic factor from the walls. Precipitin titres of $\mathrm{HCl}$ extracts of portions of walls before and after trypsin treatment were 64 and $\mathrm{O}$ respectively. These results are consistent with the soluble fraction of disintegrated bacteria containing membrane teichoic acid and the crude wall preparations being contaminated with membrane teichoic acid, since true cell wall teichoic acids are not released by trypsin treatment.

\section{Serological reactions of membrane teichoic acid from Lactobacillus casei Ro-94}

The titre of the teichoic acid preparation ( $\mathrm{I} \mathrm{mg} / \mathrm{ml}$ ) with antiserum $\mathrm{A22} / 300$ by [precipitin ring test was 640 , and a reaction of identity in the immunodiffusion test was seen 
with acid extracts of representative strains of lactobacilli and other reacting organisms, indicating that the antigenic determinant was the same in the teichoic acid and in the extracts.

\section{Properties of membrane teichoic acid from Lactobacillus casei $\mathrm{RO}-94$}

Chromatography of acid hydrolysates revealed glycerol, glycerol mono- and diphosphates and glucose. The only ninhydrin-positive material in the hydrolysates had an $R_{F}$ identical with alanine. These products are typical for those described for glycerol teichoic acids. The preparation contained: phosphorus, I6\%; hexose, $5.8 \%$; glucose, $5.2 \%$; and alanine, $4 \%$. The molar ratio of hexose: alanine:phosphorus is approximately $0 \cdot 6: 0 \cdot \mathrm{I}: \mathrm{I}$. These analyses are indicative of a glycerol teichoic acid, the product resembling the 'intracellular' teichoic acid from Lactobacillus casei ATcC 7469 (Kelemen \& Baddiley I96I) and the lipoteichoic acid from strain RO-94 (Wicken \& Knox, 197I); both of these strains belong to serological group C (Sharpe, I955; Sharpe \& Wheater, 1957).

\section{Reactions of teichoic acid preparations from different organisms with antiserum A22/300}

In the qualitative ring precipitin test, strong reactions were given by the preparation from Lactobacillus casei Ro-94, the lipoteichoic acids from Lactobacillus groups A, B, C, D and F and the streptococcal polyglycerophosphate. As determined by quantitative precipitin test, the amount of antibody reacting with the different preparations ranged from $9 \cdot 1$ to I0.7 mg/ml. No reaction occurred with Bacillus stearothermophilus or L. plantarum AB4I and cro6 glycerol teichoic acids, which do not contain glycerol linked I $\rightarrow 3$ through phosphodiester groups (Wicken, I966; Adams et al. 1969), indicating that this linkage is important for serological reactivity. After removal of antibodies reacting with streptococcal polyglycerophosphate the antiserum no longer reacted with the other teichoic acid preparations, suggesting that the antibodies were reacting only with the polyglycerophosphate backbone common to all these teichoic acids. The reaction between the membrane teichoic acid from Lactobacillus casei RO-94 (I $2.5 \mu \mathrm{g}$ ) and antiserum A22/300 (50 $\mu \mathrm{l}$ ) was not inhibited by $100 \mu \mathrm{mol}$ of glucose but was inhibited $43 \%$ by $160 \mu \mathrm{mol}$ of $\alpha$-glycerophosphate. $\mathrm{G}_{3} \mathrm{P}_{2}(2 \mu \mathrm{mol})$ inhibited the reaction of antiserum A22/300 (I5 $\left.\mu \mathrm{l}\right)$ with lipoteichoic acid from $L$. casei $\mathrm{RO}-94(20 \mu \mathrm{g})$ and $L$. helveticus $(5 \mu \mathrm{g})$ by $62 \%$ and $30 \%$ respectively. The reaction of the $L$. helveticus lipoteichoic acid was not inhibited by $50 \mu$ mol methyl $\alpha$-Dglucoside; approximately half of the glycerol residues of this teichoic acid are substituted with $\alpha$-D-glucosyl residues (Knox \& Wicken, I97I).

Precipitin reactions with antisera prepared against other micro-organisms. Antisera against Lactobacillus casei $\mathrm{C} 2$ and Leuconostoc mesenteroides $\mathrm{NCDO} 768$ gave the same pattern of reactions as those of the original A22/300 antiserum although the precipitin reaction was weaker (measured by titrating the antisera against extracts by the ring precipitin method). Only one out of six antisera to L. acidophilus A22 gave similar cross-reactions, the other antisera reacting only with the homologous type antigen.

\section{DISCUSSION}

Lactobacilli, some pediococci and leuconostocs contain a serologically active component reacting with an antiserum against a strain of Lactobacillus acidophilus. The ability of rabbits to produce such antisera was not consistent, as only two out of seven responded. The serologically reactive component isolated from L.casei $\mathrm{RO}-94$ (which lacks a wall teichoic acid) was identified as a membrane glycerol teichoic acid. Teichoic acids containing $\mathrm{I} \rightarrow 3$ 
linked glycerol phosphate units probably occur as membrane components of all Grampositive bacteria (Archibald, Baddiley \& Blumson, I968). The reaction of antiserum A22/300 with membrane glycerol lipoteichoic acid from this and other species of lactobacilli indicates that this component could account for the reaction of extracts of the various groups of bacteria.

Several authors have indicated the presence of a common antigen in a wide variety of Gram-positive organisms (Rantz, Randall \& Zuckerman, 1956; McCarty, 1959; Jackson \& Moskowitz, I966; Moskowitz, 1966; McLoughlin \& Stewart, 197I).

The reaction of the antiserum with extracts from a wide variety of organisms depends on two features: antiserum A22/300 has a high antibody content, approximately $10 \mathrm{mg} / \mathrm{ml}$, so that even low antigen concentrations would be detected; the antibody specificity is directed towards the polyglycerophosphate 'back-bone' of the teichoic acids. The serum reacted equally well with glycerol teichoic acids differing in sugar substitution and both $\alpha$-glycerophosphate and glycerol-phosphoryl-glycerol-phosphoryl-glycerol inhibited the reaction. Earlier studies with different sera (Knox \& Wicken, I97I) had shown that the reaction of these teichoic acids was not due to unsubstituted polyglycerophosphate in the preparations.

Membrane teichoic acids isolated from lactobacilli representing different serological groups differ in their sugar substitution, but have been shown to contain the $\mathrm{I} \rightarrow 3$ linked glycerol phosphate units, i.e. Lactobacillus casei 7469 group C (Kelemen \& Baddiley, I96I), L. fermenti (Wicken \& Knox, 1970) and L. helveticus (Knox \& Wicken, 197I). Because of the common backbone structure, cross-reactions occur when antibodies are specific for this part of the teichoic acid molecule. Specificity for $\mathrm{I} \rightarrow 3$ linkage of glycerol through phosphodiester groups was indicated by the precipitation inhibition by $\mathrm{G}_{3} \mathbf{P}_{2}$ which contains $\mathrm{I} \rightarrow 3$ linkages, whereas wall teichoic acid from Bacillus stearothermophilus which contains $2 \rightarrow 3$ linkages did not react.

In other studies on the antigenicity and serological cross-reactions of teichoic acids from lactobacilli (Knox et al. 1970; Wicken \& Knox, I97I), teichoic acids having a low degree of glycosidic substitution induced antisera of varying degrees of specificity to the glycosidic substituents, some rabbits giving only antibodies to the polyglycerophosphate 'back-bone'. The latter type of sera can cross-react, as has been shown above for serum A22/300, with any glycerol teichoic acid irrespective of the nature and extent of its glycosidic substitution, provided that the 'back-bone' structure of the polymer meets the required specificity. Consequently we suggest that the wide range of positive ring and immunodiffusion tests obtained with serum A22/300 against acid extracts of different organisms indicates only the presence of 1 : 3-phosphodiester linked glycerol teichoic acids in these extracts. The lack of reactivity of serum A22/300 with extracts of some bacteria, including streptococci, probably reflects either degradation or poor extraction of the antigenic determinant, and this extraction method may be optimal for lactobacilli. This may explain why acid extracted teichoic acid from group D streptococci did not react, whereas isolated lipoteichoic acids from group D did react with sera of similar specificity (Wicken \& Knox, unpublished observations). Acid extracted teichoic acid lacks the glycolipid moiety of lipoteichoic acid and is in consequence of lower molecular size as well as reactivity in precipitin reactions (Knox et al. 1970).

The authors wish to thank Mr B. A. Phillips and Mrs Sandra A. Christopherson for expert technical assistance and the National Health and Medical Research Council for support to K. W. K. and A. J. W. 


\section{REFERENCES}

Adams, J. B., Archibald, A. R., Baddiley, J., Coapes, H. E. \& Davison, A. L. (i969). Teichoic acids possessing phosphate-sugar linkages in strains of Lactobacillus plantarum. Biochemical Journal II3, I9II93.

Archibald, A. R., Baddiley, J. \& Blumsom, N. L. (1968). The teichoic acids. Advances in Enzymology 30, 223-253.

Baddiley, J., Buchanan, J. G., Rajbhandary, U. L. \& Sanderson, A. R. (I962). Teichoic acid from the walls of Staphylococcus aureus $\mathrm{H}$ : Structure of the $N$-acetylglucosaminylribitol residues. Biochemical Journal 82, 439-448.

Baddiley, J. \& Davison, A. L. (1961). The occurrence and location of teichoic acids in lactobacilli. Journal of General Microbiology 24, 295-299.

Bergmeyer, H-U. \& Bernt, E. (1965). In Methods of Enzymatic Analysis, pp. 123-I30. Edited by H-U. Bergmeyer. London: Academic Press.

Chatterjee, A. N. (1969). Use of bacteriophage-resistant mutants to study the nature of the bacteriophage receptor site of Staphylococcus aureus. Journal of Bacteriology 98, 519-527.

Chen, P. S., Toribara, T. Y. \& WARner, H. (1956). Microdetermination of phosphorus. Analytical Chemistry 28, $1756-1758$.

Dubois, M., Gilles, K. A., Hamilton, J. K., Rebers, P. A. \& Smith, F. (1956). Colorimetric method for determination of sugars and related substances. Analytical Chemistry 28, 350-356.

Heidelberger, M. \& MacPherson, C. F. C. (1943). Quantitative micro-estimation of antibodies in the sera of man and other animals. Science, New York 97, 405-406.

JACKSON, R. W. \& Moskowitz, M. (I966). Nature of a red cell sensitizing substance from streptococci. Journal of Bacteriology 91, 2205-2209.

Jones, D. \& Shattock, P. M. F. (1960). The location of the group antigen of group D Streptococcus. Journal of General Microbiology 23, 335-343.

Kelemen, M. V. \& Baddiley, J. (I96I). Structure of the intracellular glycerol teichoic acid from Lactobacillus casei ATCC 7469. Biochemical Journal 8o, 246-254.

KNox, K. W. (1963). Isolation of group specific products from Lactobacillus casei and L. casei var. rhamnosus. Journal of General Microbiology 31, 59-72.

Knox, K. W., Hewett, M. J. \& Wicken, A. J. (1970). Studies on the group F antigen of lactobacilli: antigenicity and serological specificity of teichoic acid preparations. Journal of General Microbiology 60 , 303-3I3.

Knox, K. W. \& Wicken, A. J. (I971). Serological properties of the wall and membrane teichoic acids from Lactobacillus helveticus NCIB 8025. Journal of General Microbiology 63, 237-248.

Knox, K. W. \& WICKEN, A. J. (1972). Serological studies on the teichoic acids of Lactobacillus plantarum NCIB 7220. Infection and Immunity (in the Press).

LANCEFIELD, R. C. (1933). A serological differentiation of human and other groups of hemolytic streptococci. Journal of Experimental Medicine 57, 571-595.

Lowry, O. H., Rosebrough, N. J., FARR, A. L. \& Randall, R. J. (I95I). Protein measurement with the Folin phenol reagent. Journal of Biological Chemistry I93, 265-275.

MCCARTY, M. (1959). The occurrence of polyglycerophosphate as an antigenic component of various Gram-positive bacterial species. Journal of Experimental Medicine 109, 36I-378.

MCCARTY, M. \& LANCEFIELD, R. C. (I955). Variation in the group-specific carbohydrate of group A streptococci. I. Immunochemical studies on the carbohydrates of variant strains. Journal of Experimental Medicine I02, I I-28.

McLoughlin, M. \& Stewart, F. S. (I97I). Red cell-sensitizing antigens of lactobacilli. Journal of General Microbiology 66, 229-238.

De Man, J. C., Rogosa, M. \& Sharpe, M. E. (1960). A medium for the cultivation of lactobacilli. Journal of Applied Bacteriology 23, I30-135.

MANSI, W. (1957). The study of some viruses by the plate gel diffusion precipitin test. Journal of Comparative Pathology and Therapeutics 67, 297-303.

Mills, C. K. (1969). Agglutinating antigens of Lactobacillus jugurti ATCC 521. Journal of General Microbiology 57, 105-II4.

Moskowitz, M. (1966). Separation and properties of a red cell sensitizing substance from streptococci. Journal of Bacteriology 9r, 2200-2204. 
NAYLOR, J. \& ShARPE, M. E. (1958). Lactobacilli in Cheddar cheese. I. The use of selective media for isolation and of serological typing for identification. Journal of Dairy Research 24, 92-103.

Rantz, L. A., Randall, E. \& Zuckerman, A. (1956). Hemolysis and hemagglutination by normal and immune serums of erythrocytes treated with a nonspecies specific bacterial substance. Journal of Infectious Diseases 98, 2 I I-222.

Rosen, H. (1957). A modified ninhydrin colorimetric analysis for amino acids. Archives of Biochemistry \& Biophysics 67, 10-15.

Sharpe, M. E. (1955). A serological classification of lactobacilli. Journal of General Microbiology 12, 107122.

Sharpe, M. E. (1970). Cell wall and cell membrane antigens used in the classification of lactobacilli. International Journal of Systematic Bacteriology 20, 509-518.

Sharpe, M. E., Davison, A. L. \& Baddiley, J. (I964). Teichoic acids and group antigens in lactobacilli. Journal of General Microbiology 34, 333-340.

Sharpe, M. E. \& WheAter, D. M. (1957). Lactobacillus helveticus. Journal of General Microbiology 16, 676-679.

WICKEN, A. J. (1966). The glycerol teichoic acid from the cell wall of Bacillus stearothermophilus B65. Biochemical Journal 99, 108-I 16.

WICKEN, A. J. \& KNox, K. W. (1970). Studies on the group F antigen of lactobacilli: isolation of a teichoic acid-lipid complex from Lactobacillus fermenti NCTC 6991. Journal of General Microbiology 6o, 293-301.

WiCKEN, A. J. \& KNox, K. W. (197I). A serological comparison of the membrane teichoic acids from lactobacilli of different serological groups. Journal of General Microbiology 67, 25 I-254.

Wilkinson, S. G. (I968). Glycosyl diglycerides from Pseudomonas rubescens. Biochimica et biophysica acta $164,148-156$.

Young, F. E. \& JACKSON, A. P. (1966). Extent and significance of contamination of DNA by teichoic acid in Bacillus subtilis. Biochemical and Biophysical Research Communications 23, 490-495. 